\title{
Parabrachial Calcitonin Gene-Related Peptide Neurons Mediate Conditioned Taste Aversion
}

\author{
Matthew E. Carter, Sung Han, and $₫$ Richard D. Palmiter \\ Howard Hughes Medical Institute, Department of Biochemistry, University of Washington, Seattle, Washington 98195
}

Conditioned taste aversion (CTA) is a phenomenon in which an individual forms an association between a novel tastant and toxininduced gastrointestinal malaise. Previous studies showed that the parabrachial nucleus (PBN) contains neurons that are necessary for the acquisition of CTA, but the specific neuronal populations involved are unknown. Previously, we identified calcitonin gene-related peptide (CGRP)-expressing neurons in the external lateral subdivision of the PBN (PBel) as being sufficient to suppress appetite and necessary for the anorexigenic effects of appetite-suppressing substances including lithium chloride ( $\mathrm{LiCl}$ ), a compound often used to induce CTA. Here, we test the hypothesis that PBel CGRP neurons are sufficient and necessary for CTA acquisition in mice. We show that optogenetic activation of these neurons is sufficient to induce CTA in the absence of anorexigenic substances, whereas genetically induced silencing of these neurons attenuates acquisition of CTA upon exposure to LiCl. Together, these results demonstrate that PBel CGRP neurons mediate a gastrointestinal distress signal required to establish CTA.

Key words: CGRP; ChR2; conditioned taste aversion; CTA; parabrachial; PBN

\section{Introduction}

Conditioned taste aversion (CTA) develops when consumption of a novel taste is followed by transient gastrointestinal malaise (Welzl et al., 2001). Although the neural basis of CTA is unknown, previous research demonstrated that lesions of the parabrachial nucleus $(\mathrm{PBN})$ in rodents can cause deficits in CTA (Dilorenzo, 1988; Flynn et al., 1991; Reilly et al., 1993; Grigson et al., 1998). However, because the PBN contains subpopulations of neurons that regulate multiple functions including both taste (Rosen et al., 2011; Tokita and Boughter, 2012; Tokita et al., 2012) and appetite suppression (Becskei et al., 2007; DiPatrizio and Simansky, 2008; Wu et al., 2009; Carter et al., 2013), the molecular identity of neurons that underlie these effects is unknown.

Anatomically, the parabrachial neurons that mediate CTA may be located specifically in the lateral division of the PBN. Stereotaxically guided electrolytic lesions of only the lateral PBN attenuate CTA (Agüero et al., 1993a,b). Furthermore, injection of lithium chloride $(\mathrm{LiCl})$, a compound routinely used to cause gastrointestinal malaise and induce CTA (Rowland et al., 2004),

\footnotetext{
Received Sept. 7, 2014; revised Feb. 5, 2015; accepted Feb. 8, 2015

Author contributions: M.E.C., S.H., and R.D.P. designed research; M.E.C. and S.H. performed research; M.E.C. and S.H. analyzed data; M.E.C. and R.D.P. wrote the paper.

This work was supported by a fellowship from the Hilda and Preston Davis Foundation (M.E.C.) and in part by grants from the National Institutes of Health (DA024908) and the Klarman Family Foundation (R.D.P.). We thank Bryan Roth for the HM4Di-mCherry construct, Karl Deisseroth for mCherry and ChR2-mCherry constructs, and Susan Dymecki for the GFP-TetTox construct. Elyse Allen and Aundrea Rainwater assisted with animal husbandry. We thank members of the Palmiter lab for critical feedback and advice on this manuscript.

The authors declare no competing financial interests.

Correspondence should be addressed to Dr. Richard D. Palmiter, Department of Biochemistry, University of

Washington, Box 357350, 1705 Northeast Pacific Street, Seattle, WA 98195. E-mail: palmiter@uw.edu.

M.E. Carter's present address: Department of Biology, Williams College, Williamstown, MA 01267.

DOI:10.1523/JNEUROSCI.3729-14.2015

Copyright $\odot 2015$ the authors $\quad 0270-6474 / 15 / 354582-05 \$ 15.00 / 0$
}

activates Fos, a surrogate marker of neuronal activity, specifically in the external lateral subdivision of the PBN (PBel) (Yamamoto et al., 1992; Sakai and Yamamoto, 1997; St Andre et al., 2007).

Previously, we demonstrated that these Fos-positive neurons expressed calcitonin gene-related peptide (CGRP) and that their stimulation was sufficient to induce appetite suppression (Carter et al., 2013). Importantly, inhibition of CGRP neurons reduced appetite suppression caused by injection of $\mathrm{LiCl}$. Therefore, we hypothesized that neural activity in PBel CGRP neurons is necessary and sufficient to form a CTA. We tested this hypothesis using $\mathrm{Calca}^{\mathrm{Cre} /+}$ mice (Calca is the gene that encodes CGRP) and genetically encoded neural actuators, demonstrating a critical role for PBel CGRP neurons in mediating CTA.

\section{Materials and Methods}

Mice. All experiments were approved by the University of Washington Institutional Animal Care and Use Committee and were performed in accordance with the guidelines described in the U.S. National Institutes of Health Guide for the Care and Use of Laboratory Animals. We used exclusively heterozygous male $\mathrm{Calca}^{\mathrm{Cre} /+}$ mice, aged 7-9 weeks at the start of experimental procedures and no more than 12 weeks at the end of experimental procedures. These mice had been backcrossed onto a C57BL/6 background for more than five generations. Before stereotaxic surgery, mice were group housed and maintained with a rodent diet (Picolab, catalog \#5053) and water available ad libitum with a $12 \mathrm{~h} \mathrm{light/}$ dark cycle at $22^{\circ} \mathrm{C}$.

Virus production. Cre-dependent adeno-associated virus pAAV mCherry and ChR2-mCherry (driven by the Ef1 $\alpha$ promoter) DNA plasmids were kindly provided by Dr. Karl Deisseroth, and Cre-dependent pAAV hM4Di-mCherry (driven by the human synapsin promoter) DNA plasmids were kindly provided by Dr. Bryan Roth. The plasmid encoding AAV1-CBA-DIO-GFP-TetTox-WPRE-pA virus was prepared by inserting a GFP-TetTox cassette obtained from Dr. Susan Dymecki (Kim et al., 2009) into a generic AAV-CBA-DIO-WPRE-pA vector. AAVs were prepared in human embryonic kidney 293T cells with AAV1 coat serotype, 
purified by sucrose and $\mathrm{CsCl}$ gradient centrifugation steps, and resuspended in HEPES buffered saline solution at a titer of $\sim 2 \times 10^{9}$ viral genomes per microliter. Viral aliquots were stored at $-80^{\circ} \mathrm{C}$ before stereotaxic injection.

Stereotaxic surgery. At the start of surgical procedures, mice were anesthetized with isofluorane and placed on a small stereotaxic frame (David Kopf Instruments). Stereotaxic coordinates for the anterior-posterior plane were normalized using a correction factor $[F=($ Bregma - Lamda distance)/4.21] and based on the coordinates of Paxinos and Franklin (2013). Virus was injected unilaterally (on the left side) or bilaterally in the PBN [anteroposterior (AP), $-4.9 \mathrm{~mm}$; mediolateral (ML), $1.4 \mathrm{~mm}$; dorsoventral (DV), $3.8 \mathrm{~mm}$ ] at a rate of $0.2 \mu \mathrm{l} / \mathrm{min}$ for $2.5 \mathrm{~min}(0.5 \mu \mathrm{l}$ total volume). Note that the viral injection coordinates target the most anterior aspect of the PBN; however, the virus diffuses posteriorly to hit all lateral PBN subnuclei. This injection site improves the accuracy of injecting into the lateral PBN between the superior cerebellar peduncle (scp) and lateral wall of the pons. Also note that the presence of the scp fortuitously limits the spread of virus from the PBN region, thus preventing unintended transduction of other nearby Calca-expressing brain regions. In histological analysis of brain tissue following behavioral experiments, we found no expression of reporter proteins outside the PBel region.

After viral injection, mice used for optogenetic experiments also received unilateral surgical implantation of a mono fiber-optic cannula (Doric Lenses) above the PBN (AP, $-5.2 \mathrm{~mm}$; ML, $1.6 \mathrm{~mm}$; DV, 3.0 $\mathrm{mm})$. Cannulae were affixed to the skull with C\&B Metabond (Parkell) and dental acrylic.

Behavioral experiments. Animals were allowed to acclimate to lickometer cages for at least 1 week before experimental procedures, with dispensers for water and food pellets on the floor.

At the onset of the dark cycle of Day 0, a liquid food dispenser was added containing vanilla-flavored Ensure. One hour after the onset of the dark cycle, mice received either injection of $\mathrm{LiCl}(84 \mathrm{mg} / \mathrm{kg} ; 0.20 \mathrm{M}$ at 10 $\mathrm{ml} / \mathrm{kg}$; Fisher Scientific, catalog \#L121) or unilateral photostimulation of PBel CGRP neurons at $30 \mathrm{~Hz}$ (for $5 \mathrm{~min}$ ). The amount of Ensure consumed was calculated $15 \mathrm{~h}$ later ( $4 \mathrm{~h}$ after the onset of the light cycle), and the Ensure food dispenser was removed. These procedures were repeated on subsequent days except that mice did not receive further treatments of $\mathrm{LiCl}$ or photostimulation. For pharmacogenetic inhibition experiments, HM4Di-mCherry-transduced mice received an injection of clozapine $\mathrm{N}$-oxide (CNO; Sigma; $1 \mathrm{mg} / \mathrm{kg}$ ) at the onset of the dark cycle on the first day.

Photostimulation. Mice were allowed at least $5 \mathrm{~d}$ to acclimate to fiberoptic cables (1.5 m long, $200 \mu \mathrm{m}$ diameter; Doric Lenses) coated with opaque heat-shrink tubing before experimental sessions. During photostimulation experiments, light pulse trains ( $10 \mathrm{~ms}$ pulses $)$ were programmed using a waveform generator (Agilent Technologies, catalog \#33220A) that provided input to a blue light laser (473 nm; LaserGlow). We adjusted the light power of the laser such that the light power exiting the fiber-optic cable was $20 \mathrm{~mW}$. Using an online light transmission calculator for brain tissue (www.stanford.edu/group/dlab/cgi-bin/graph/chart.php), we estimate the light power at the PBel to be $36.2 \mathrm{~mW} / \mathrm{mm}^{-2}$. Note that this is probably a high estimation because some light is probably lost at the interface between the fiber-optic cable and the implanted fiber-optic cannula.

Histology. Mice were anesthetized with buprenorphine and perfused transcardially with PBS, $\mathrm{pH} 7.4$, followed by $4 \%$ paraformaldehyde in PBS. The brains were extracted, allowed to postfix overnight in the same fixative at $4^{\circ} \mathrm{C}$, and cryoprotected in $30 \%$ sucrose dissolved in PBS for an additional $24 \mathrm{~h}$ at $4^{\circ} \mathrm{C}$. Each brain was sectioned at $30 \mu \mathrm{m}$ on a cryostat (Leica Microsystems) and collected in cold $1 \times$ PBS.

For immunohistochemistry experiments, sections were washed three times in PBS with $0.2 \%$ Triton X-100 (PBST) for $10 \mathrm{~min}$ at room temperature. Sections were then incubated in a blocking solution composed of PBST with 3\% normal donkey serum (Jackson ImmunoResearch, catalog \#017-000-121) for $1 \mathrm{~h}$. For primary antibody exposure, sections were incubated in rabbit anti-c-Fos (1:2000; Calbiochem, catalog \#PC38) in blocking solution at $4^{\circ} \mathrm{C}$ for $\sim 20 \mathrm{~h}$. After three 10 min washes in PBST, sections were incubated in Alexa Fluor 488 donkey anti-rabbit IgG (1: 200; Jackson Immunoresearch, catalog \#711-545-152) in block solution for $1 \mathrm{~h}$ at room temperature. Finally, sections were washed three times in PBS.

Sections were mounted in PBS onto SuperFrost Plus glass slides (VWR, catalog \#48311-703) and coverslipped with Dapi Fluoromount-G (Southern Biotech, catalog $\# 0100-20)$. Slides were stored in the dark at $4^{\circ} \mathrm{C}$ before microscopy and image acquisition.

Quantification of colocalization of Fos and mCherry in the PBN (see Fig. $2 A-C$ ) was performed on adjacent sections from approximately -4.90 to $-5.50 \mathrm{~mm}$ from Bregma (exactly 21 sections per mouse). All quantification analysis was performed by an investigator (M.E.C.) blinded to the identity of the conditions used to induce Fos.

Analysis was performed using a Nikon upright epifluorescent microscope with a QImaging camera. Images were minimally processed using Photoshop CS5 (Adobe Systems) to enhance the brightness and contrast for optimal representation of the data. All digital images were processed in the same way between experimental conditions to avoid artificial manipulation between different datasets.

Statistics. All data were analyzed using Prism 6.0 (GraphPad Software). Data were exported into Illustrator CS5 (Adobe Systems) for preparation of the figures.

\section{Results}

\section{Optogenetic stimulation of PBel CGRP neurons is sufficient} to induce CTA

To test the role of PBel CGRP neurons in CTA, we first developed a paradigm to induce CTA by acclimating mice to lickometer chambers for $7 \mathrm{~d}$ and subsequently allowing them access to a novel tastant, vanilla-flavored Ensure, at the onset of the dark (active) period, when mice typically consume the most food (Fig. $1 A$ ). One hour later, we administered $\mathrm{LiCl}$ ( $84 \mathrm{mg} / \mathrm{kg}$, i.p.) or saline and allowed mice ad libitum access to Ensure and mouse chow over the next $5 \mathrm{~d}$. Before injection of $\mathrm{LiCl}$ or saline, there was no significant difference in food consumption (measured by number of licks) between the two experimental groups during the first hour of Ensure exposure $(n=8$ mice per condition, $p=$ 0.56). However, LiCl-injected animals developed a CTA and consumed significantly less Ensure than saline-injected animals during the first $3 \mathrm{~d}$ following $\mathrm{LiCl}$ injection $(n=8$ mice per condition; interaction of condition $\times$ day, $F_{(4,56)}=21.72, p<$ 0.0001; Fig. $1 B$ ). To test whether the pairing of $\mathrm{LiCl}$ and a familiar tastant could induce CTA, we repeated the previous experiment but exposed mice to Ensure ad libitum for $5 \mathrm{~d}$ before $\mathrm{LiCl}$ injection. This paradigm did not produce a significant CTA to Ensure, demonstrating the necessity that the tastant be novel ( $n=8$ mice per condition; no interaction of condition $\times$ day, $F_{(4,56)}=1.23$, $p=0.2913$; Fig. $1 C$ ). We also found that daily pretreatment with $\mathrm{LiCl}$ for $5 \mathrm{~d}$ before exposure to the novel tastant blocked CTA ( $n=8$ mice per condition; no interaction of condition $\times$ day, $F_{(4,56)}=1.015, p=0.4076$; Fig. $\left.1 D\right)$. Together, these results show that pairing Ensure with $\mathrm{LiCl}$ injection causes a CTA for Ensure, but the association occurs only if both the tastant and the visceral malaise induced by $\mathrm{LiCl}$ are novel.

To determine whether PBel CGRP neurons are sufficient to induce CTA, we unilaterally injected AAV carrying a Cre-dependent channelrhodopsin-2 transgene (AAV1-DIO-ChR2-mCherry) (Yizhar et al., 2011) or control transgene (AAV1-DIO-mCherry) into the PBNs of Calca ${ }^{\mathrm{Cre} /+}$ mice (Fig. $1 E$ ). Instead of $\mathrm{LiCl}$, we paired access to Ensure with in vivo photostimulation of CGRP neurons for $5 \mathrm{~min}$ at $30 \mathrm{~Hz}$. Stimulation of these neurons produced a significant CTA $(n=9$ mice per condition; interaction of condition $\times$ day, $F_{(4,64)}=29.61, p<0.0001$; Fig. $\left.1 F\right)$ in a manner that mimicked LiCl-mediated CTA (Fig. $1 B$ ). These effects were lost when mice received daily activation ( $5 \mathrm{~min}$ per day) of CGRP neurons in the PBel before exposure to Ensure $(n=9$ mice per condition; no interaction of condition $\times$ day, $F_{(4,64)}=0.5866$, 

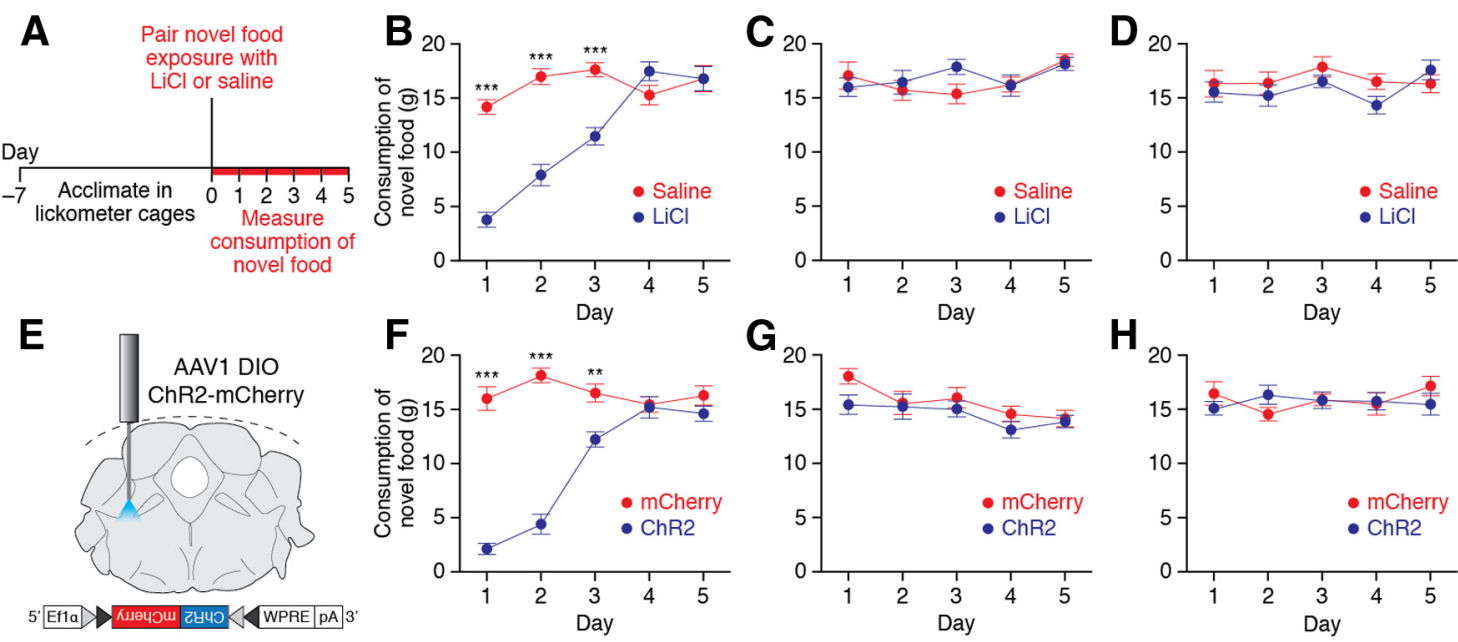

Figure 1. Optogenetic stimulation of PBel CGRP neurons is sufficient to mimic LiCl-induced CTA. $\boldsymbol{A}$, Paradigm used to cause CTA. $\boldsymbol{B}$, Pairing LiCl with novel tastant causes CTA ( $n=8$ mice per condition). C, Daily exposure to novel tastant $5 \mathrm{~d}$ before exposure to LiCl prevents CTA $(n=8$ mice per condition). $\boldsymbol{D}$, Daily exposure to LiCl $5 \mathrm{~d}$ before exposure to novel tastant prevents CTA ( $n=$ 8 mice per condition). $\boldsymbol{E}$, Placement of fiber-optic implant in the PBN in a Calca ${ }^{\text {Cre/+ }}$ animal injected with AAV-DI0-ChR2-mCherry. $\boldsymbol{F}$, Pairing photostimulation of PBel CGRP neurons with novel tastant causes CTA ( $n=9$ mice per condition). $\boldsymbol{G}$, Daily exposure to PBel CGRP photostimulation 5 d before exposure to novel tastant prevents CTA ( $n=9$ mice per condition). $\boldsymbol{H}$, Daily exposure to $\mathrm{LiCl} 5 \mathrm{~d}$ before exposure to novel tastant prevents PBel CGRP neuron-mediated CTA ( $n=9$ mice per condition). All values represent the mean \pm SEM. ${ }^{* *} p<0.001 ;{ }^{* * *} p<0.0001$ (Bonferroni post hoc test between conditions).
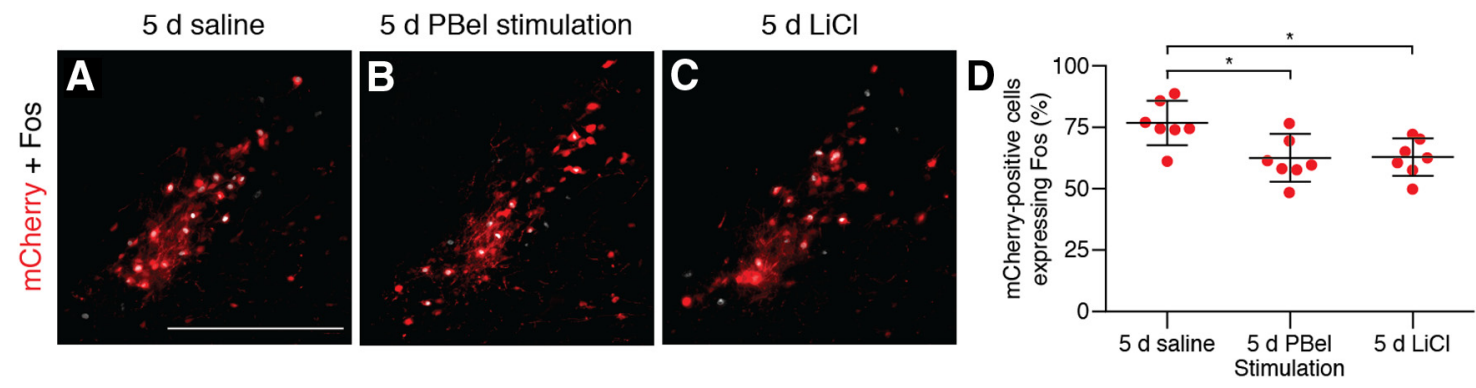

Figure 2. Prior LiCl or PBel CGRP stimulation reduces subsequent PBel CGRP activation during (TA. A-C, Representative histological examples of coincidence of mCherry (red) and Fos (white) expression in animals following LiCl injection after $5 \mathrm{~d}$ daily exposure to saline (A), PBel CGRP photostimulation (B), or LiCl administration (C). Scale bar, $500 \mu \mathrm{m}$. D, Quantification of Fos expression $2 \mathrm{~h}$ after injection with $\mathrm{LiCl}$ ( $n=7$ mice per condition). Values represent the mean $\pm \mathrm{SD} .{ }^{*} p<0.05$ (Tukey's multiple comparisons test between conditions).

$p=0.6735$; Fig. $1 G)$. These effects were also lost when mice received daily pretreatment of $\mathrm{LiCl}$ for $5 \mathrm{~d}(n=9$ mice per condition; no interaction of condition $\times$ day, $F_{(4,64)}=0.1357, p=$ 0.2586; Fig. $1 H$ ). Together, these results indicate that photoactivation of CGRP neurons is sufficient to induce CTA if it is novel, or prevent CTA if it is administered before exposure to a novel taste.

Importantly, there was no effect of ChR2-mCherry expression on body weight in the days leading up to acquisition of the CTA (no interaction of experimental group $\times$ day, $F_{(55,576)}=0.006$, $p>0.99$ ). Additionally, there were no significant differences in body weight between mice with induced CTA and control mice with no induced CTA (no interaction of experimental group $X$ day, $\left.F_{(44,480)}=0.0044, p>0.99\right)$, demonstrating that CTA caused an aversion specific to Ensure and not an aversion to eating in general. This result is consistent with our previous finding that the decrease in food intake during stimulation of PBel CGRP neurons is rapidly reversible and does not cause a general, longterm reduction of feeding (Carter et al., 2013).

Repeated daily PBel CGRP neuron stimulation or LiCl administration slightly reduces subsequent activation of PBel CGRP neurons

To examine whether daily stimulation of PBel CGRP neurons for $5 \mathrm{~d}$ blocked subsequent CTA by reducing neural activity in PBel neurons, we exposed $\mathrm{Calca}^{\mathrm{Cre} /+}$ mice transduced with AAVDIO-mCherry to $5 \mathrm{~d}$ of intraperitoneal saline administration, $5 \mathrm{~d}$ of PBel photostimulation, or $5 \mathrm{~d}$ of $\mathrm{LiCl}$ administration. Then the injected animals were injected with $\mathrm{LiCl}$ and killed $2 \mathrm{~h}$ later to examine the expression of Fos in mCherry-positive neurons (Fig. $2 A-C)$. We found a modest but significant reduction in the percentage of mCherry-positive neurons expressing Fos in animals exposed to either photostimulation of CGRP neurons in the PBel or LiCl administration compared with animals exposed to saline administration $(n=7$ mice per condition; difference between treatments, $F_{(2,18)}=62.90, p<0.0085$; Fig. $\left.2 D\right)$, suggesting that the $\mathrm{PBel}$ may be a potential site of plasticity for previous exposure to stimuli that cause CTA. However, because these neurons continue to show expression of Fos following these treatments, these results also demonstrate that $\mathrm{LiCl}$ can continue to activate PBel CGRP neurons after multiple days of exposure.

\section{PBel CGRP neural activity is necessary for a normal CTA response to $\mathrm{LiCl}$}

To determine whether PBel CGRP neurons are necessary for LiCl-mediated CTA, we bilaterally transduced these neurons with AAV carrying a Cre-dependent $\mathrm{hM}_{4} \mathrm{Di}$-mCherry transgene (Armbruster et al., 2007) or mCherry control transgene and administered CNO (1 mg/kg; i.p.) during novel exposure to Ensure 
A

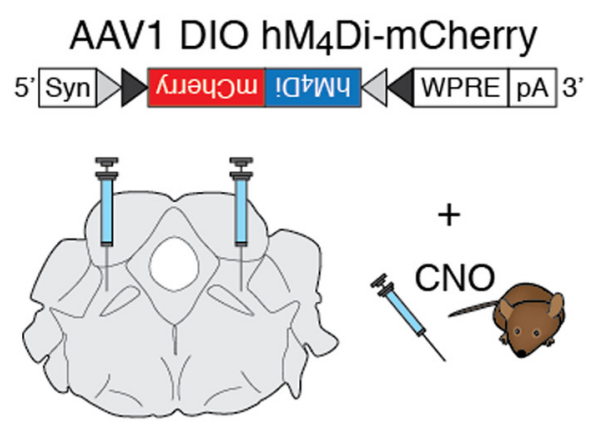

C

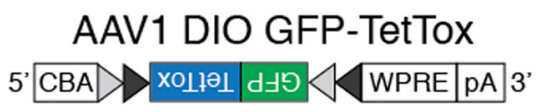

B

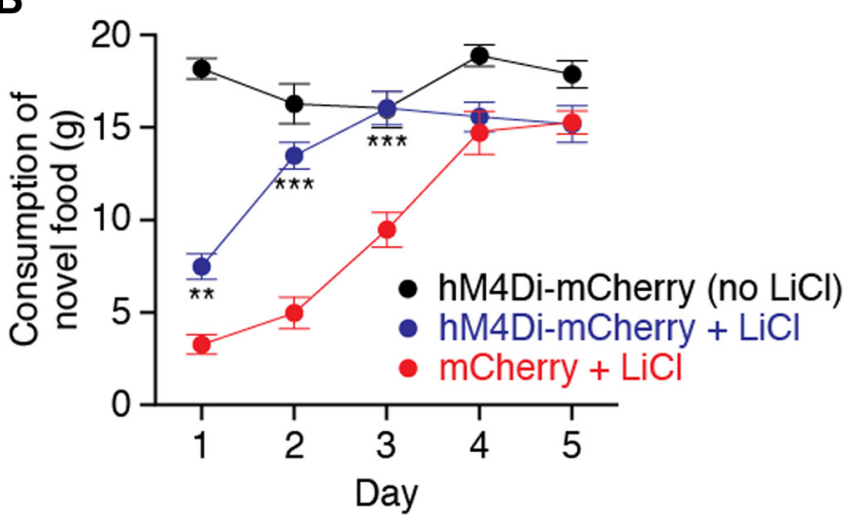

D

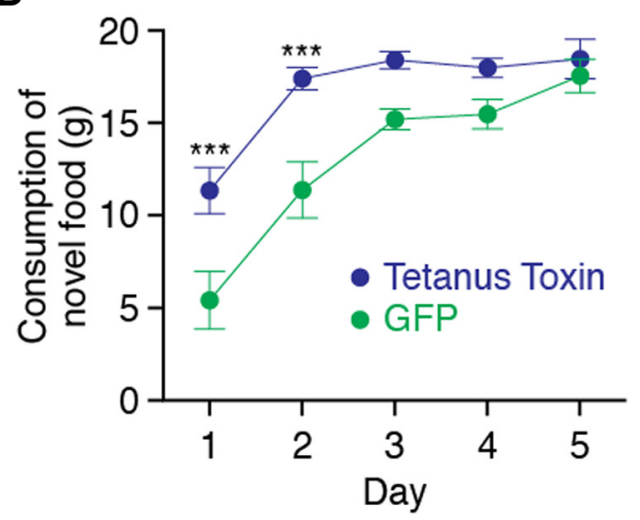

Figure 3. Genetic inhibition or silencing of PBel CGRP neurons attenuates LiCl-mediated CTA. $A, A A V-D I 0-h M_{4}$ Di-mCherry transgene bilaterally injected into the PBN. $\boldsymbol{B}$, Pharmacogenetic inhibition of CGRP neurons during pairing of LiCl and novel tastant attenuates CTA ( $n=9$ mice per condition). C, AAV-DI0-GFP-TetTox transgene bilaterally injected into the PBN. $\boldsymbol{D}$, TetTox-induced silencing of PBel CGRP neurons attenuates LiCl-mediated CTA ( $n=9$ mice per condition). All values represent the mean \pm SEM. ${ }^{* *} p<0.001 ;{ }^{* * *} p<0.0001$ (Bonferroni post hoc test between conditions).

paired with injection of LiCl (Fig. 3A). Inhibition of CGRP neurons with $\mathrm{CNO}$ in animals expressing $\mathrm{hM}_{4} \mathrm{Di}$-mCherry in CGRP neurons significantly attenuated the CTA response compared with control mice expressing only mCherry $(n=9$ mice per condition; interaction of viral genotype $\times$ day, $F_{(8,96)}=12.34$, $p<0.0001$; Fig. $3 B$ ), although it did not completely block the CTA response on the first day.

To independently confirm these results, we also bilaterally transduced PBel CGRP neurons with AAV carrying a Cre-dependent tetanus toxin (AAV-DIO-GFP-TetTox) transgene (Kim et al., 2009) or a GFP control virus (Fig. $3 C$ ). When expressed in neurons, TetTox blocks synaptic transmission without resulting in cell death (Yamamoto et al., 2003). Consistent with hM4Di-mediated inactivation, we found that $\mathrm{LiCl}$-mediated CTA was significantly attenuated in mice expressing TetTox in CGRP neurons compared with control mice with GFP only $(n=9$ mice per condition, interaction of viral genotype $\times$ day, $F_{(4,80)}=2.491, p<0.0497$; Fig. $\left.3 D\right)$. These results demonstrate that inhibition or silencing of CGRP neurons causes a significant reduction in CTA for Ensure paired with $\mathrm{LiCl}-$ induced malaise.

\section{Discussion}

Together, these findings demonstrate that PBel CGRP neurons are sufficient to cause CTA and are necessary for a normal CTA response to LiCl. Interestingly, our finding that CTA caused by optogenetic stimulation of PBel CGRP neurons could be blocked both by prior photostimulation and also by previous $\mathrm{LiCl}$ administration indicates that mice may interpret PBel CGRP stimulation and $\mathrm{LiCl}$ adminis- tration as being equivalent. Thus, our results build upon previous findings that implicate the lateral PBN in regulating CTA by demonstrating that PBel CGRP neurons mediate a gastrointestinal distress signal required to establish CTA.

Inhibiting PBel CGRP neural activity (Fig. $3 A, B$ ) or silencing PBel CGRP synaptic activity (Fig. 3C,D) reduced, but did not completely abolish, the acquisition of CTA. These results suggest that additional circuits exist, independent of PBel CGRP neurons, which participate in LiCl-mediated CTA. Administration of $\mathrm{LiCl}$, as well as other abdominal irritants and emetic agents, causes expression of Fos in the nucleus of the solitary tract (NTS) and area postrema (Yamamoto et al., 1992; Thiele et al., 1996; Sakai and Yamamoto, 1997). Lesioning or suppressing neural activity in the area postrema attenuates LiCl-induced CTA and suppresses Fos expression in downstream brain areas (Wang et al., 1997; Spencer et al., 2012). Therefore, projections from the NTS or area postrema that bypass the PBel could provide alternate neural pathways by which visceral signals could integrate to form a CTA.

However, it is worth noting that it is technically more difficult to inhibit a neural population than to active one. Activating a fraction of relevant neurons is often sufficient to achieve a maximal effect, whereas nearly all of the neurons have to be inhibited for complete suppression. Because the PBel is an elongated structure, it is possible that we did not transduce all CGRP-expressing neurons, and any unsilenced neurons were sufficient to induce a residual CTA. 
Our study examined the effect of inhibiting/silencing PBel CGRP neurons on acquisition, but not subsequent expression, of CTA. The acquisition and expression of a CTA can be defined as two separate behavioral processes (Parker, 2003), and it is possible that the PBel is also necessary for the expression of a previously established CTA. Therefore, future studies should focus on the role of the PBel in the reduction of food intake in the days following expression of a CTA in addition to the induction of the CTA itself.

Although prior activation of PBel CGRP neurons for $5 \mathrm{~d}$ modestly reduces Fos expression caused by LiCl (Fig. 2), Fos expression continues to occur even in the absence of CTA, suggesting that the association between a novel tastant and environmental stimulus occurs primarily in a downstream location. A likely region is the amygdala, where visceral malaise and sensory taste signals are thought to converge (Koh et al., 2003; Reilly and Bornovalova, 2005). We showed previously that PBel CGRP neurons send dense projections to the central amygdala (CeA; Carter et al., 2013), a region that is also necessary and sufficient for the acquisition of CTA (Bahar et al., 2003; Ma et al., 2011; Kwon and Houpt, 2012). Therefore, we propose that PBel CGRP neurons constitute a necessary and sufficient hub for acquiring a CTA, whereas the association occurs downstream, presumably in the CeA.

\section{References}

Agüero A, Arnedo M, Gallo M, Puerto A (1993a) The functional relevance of the lateral parabrachial nucleus in lithium chloride-induced aversion learning. Pharmacol Biochem Behav 45:973-978. CrossRef

Agüero A, Arnedo M, Gallo M, Puerto A (1993b) Lesions of the lateral parabrachial nuclei disrupt aversion learning induced by electrical stimulation of the area postrema. Brain Res Bull 30:585-592. CrossRef Medline

Armbruster BN, Li X, Pausch MH, Herlitze S, Roth BL (2007) Evolving the lock to fit the key to create a family of $\mathrm{G}$ protein-coupled receptors potently activated by an inert ligand. Proc Natl Acad Sci U S A 104:51635168. CrossRef Medline

Bahar A, Samuel A, Hazvi S, Dudai Y (2003) The amygdalar circuit that acquires taste aversion memory differs from the circuit that extinguishes it. Eur J Neurosci 17:1527-1530. CrossRef Medline

Becskei C, Grabler V, Edwards GL, Riediger T, Lutz TA (2007) Lesion of the lateral parabrachial nucleus attenuates the anorectic effect of peripheral amylin and CCK. Brain Res 1162:76-84. CrossRef Medline

Carter ME, Soden ME, Zweifel LS, Palmiter RD (2013) Genetic identification of a neural circuit that suppresses appetite. Nature 503:111-114. CrossRef Medline

Dilorenzo PM (1988) Long-delay learning in rats with parabrachial pontine lesions. Chem Senses 13:219-229. CrossRef

DiPatrizio NV, Simansky KJ (2008) Activating parabrachial cannabinoid CB1 receptors selectively stimulates feeding of palatable foods in rats. J Neurosci 28:9702-9709. CrossRef

Flynn FW, Grill HJ, Schulkin J, Norgren R (1991) Central gustatory lesions: II. Effects on sodium appetite, taste-aversion learning, and feeding behaviors. Behav Neurosci 105:944-954. CrossRef Medline

Grigson PS, Reilly S, Shimura T, Norgren R (1998) Ibotenic acid lesions of the parabrachial nucleus and conditioned taste aversion: further evidence for an associative deficit in rats. Behav Neurosci 112:160-171. CrossRef Medline

Kim JC, Cook MN, Carey MR, Shen C, Regehr WG, Dymecki SM (2009) Linking genetically defined neurons to behavior through a broadly applicable silencing allele. Neuron 63:305-315. CrossRef Medline
Koh MT, Wilkins EE, Bernstein IL (2003) Novel tastes elevate c-fos expression in the central amygdala and insular cortex: implication for taste aversion learning. Behav Neurosci 117:1416-1422. CrossRef Medline

Kwon B, Houpt TA (2012) Mitogen-activated protein kinase in the amygdala plays a critical role in lithium chloride-induced taste aversion learning. Neurobiol Learn Mem 97:132-139. CrossRef Medline

Ma L, Wang DD, Zhang TY, Yu H, Wang Y, Huang SH, Lee FS, Chen ZY (2011) Region-specific involvement of BDNF secretion and synthesis in conditioned taste aversion memory formation. J Neurosci 31:2079-2090. CrossRef Medline

Parker LA (2003) Taste avoidance and taste aversion: evidence for two different processes. Learn Behav 31:165-172. CrossRef Medline

Paxinos G, Franklin KB (2013) The mouse brain in stereotaxic coordinates, 4th ed. San Diego: Elsevier.

Reilly S, Bornovalova MA (2005) Conditioned taste aversion and amygdala lesions in the rat: a critical review. Neurosci Biobehav Rev 29:1067-1088. CrossRef Medline

Reilly S, Grigson PS, Norgren R (1993) Parabrachial nucleus lesions and conditioned taste aversion: evidence supporting an associative deficit. Behav Neurosci 107:1005-1017. CrossRef Medline

Rosen AM, Victor JD, Di Lorenzo PM (2011) Temporal coding of taste in the parabrachial nucleus of the pons of the rat. J Neurophysiol 105:18891896. CrossRef Medline

Rowland NE, Nasrallah NA, Robertson KL (2004) LiCl-induced flavor avoidance compared between rats and mice using a nondeprivation protocol. Am J Physiol Regul Integr 286:R260-R268. Medline

Sakai N, Yamamoto T (1997) Conditioned taste aversion and c-fos expression in the rat brainstem after administration of various USs. Neuroreport 8:2215-2220. CrossRef Medline

Spencer CM, Eckel LA, Nardos R, Houpt TA (2012) Area postrema lesions attenuate LiCl-induced c-Fos expression correlated with conditioned taste aversion learning. Physiol Behav 105:151-160. CrossRef Medline

St Andre J, Albanos K, Reilly S (2007) C-fos expression in the rat brain following lithium chloride-induced illness. Brain Res 1135:122-128. CrossRef Medline

Thiele TE, Roitman MF, Bernstein IL (1996) c-Fos induction in rat brainstem in response to ethanol- and lithium chloride-induced conditioned taste aversions. Alcoholism Clinand Exp Res 20:1023-1028. CrossRef

Tokita K, Boughter JD Jr (2012) Sweet-bitter and umami-bitter taste interactions in single parabrachial neurons in C57BL/6J mice. J Neurophysiol 108:2179-2190. CrossRef Medline

Tokita K, Yamamoto T, Boughter JD Jr (2012) Gustatory neural responses to umami stimuli in the parabrachial nucleus of C57BL/6J mice. J Neurophysiol 107:1545-1555. CrossRef Medline

Wang Y, Lavond DG, Chambers KC (1997) Cooling the area postrema induces conditioned taste aversions in male rats and blocks acquisition of LiCl-induced aversions. Behav Neurosci 111:768-776. CrossRef Medline

Welzl H, D’Adamo P, Lipp HP (2001) Conditioned taste aversion as a learning and memory paradigm. Behav Brain Res 125:205-213. CrossRef Medline

Wu Q, Boyle MP, Palmiter RD (2009) Loss of GABAergic signaling by AgRP neurons to the parabrachial nucleus leads to starvation. Cell 137:12251234. CrossRef Medline

Yamamoto M, Wada N, Kitabatake Y, Watanabe D, Anzai M, Yokoyama M, Teranishi Y, Nakanishi S (2003) Reversible suppression of glutamatergic neurotransmission of cerebellar granule cells in vivo by genetically manipulated expression of tetanus neurotoxin light chain. J Neurosci 23:6759-6767. Medline

Yamamoto T, Shimura T, Sako N, Azuma S, Bai WZ, Wakisaka S (1992) C-fos expression in the rat brain after intraperitoneal injection of lithium chloride. Neuroreport 3:1049-1052. CrossRef Medline

Yizhar O, Fenno LE, Davidson TJ, Mogri M, Deisseroth K (2011) Optogenetics in neural systems. Neuron 71:9-34. CrossRef Medline 